\title{
引張限界ひずみによる免震構造物設計のための積層ゴムの引張特性の評価 EVALUATION OF TENSILE CHARACTERISTICS OF RUBBER BEARINGS TO DESIGN
SEISMICALLY ISOLATED STRUCTURE BY DESIGN LIMIT VALUE OF TENSILE STRAIN
}

森 隆浩*1, 中村昌弘 ${ }^{* 2}$, 室田伸夫*3, 北村春幸*4, 佐藤利 昭*5

Takahiro MORI, Masahiro NAKAMURA, Nobuo MUROTA, Haruyuki KITAMURA and Toshiaki SATO

\begin{abstract}
Generally, in the case of designing seismically isolated structure, tensile design limit value for laminated rubber bearing is defined by tensile stress. The critical value is defined as $1 \mathrm{MPa}$ independent of type of rubber bearing. However, in case seismically isolated structure is designed using design limit tensile stress value, tensile stress often transcends $1 \mathrm{MPa}$. If tensile stress transcends design limit tensile stress, special device which can avoid generation of tensile deformation is used. This becomes an obstacle to designing seismically isolated structure. In order to alleviate this obstacle, the method which tensile design limit value is defined by tensile strain is proposed in this paper. First, outline of tensile test condition to define design limit value of tensile strain and its test result are shown. Next, design limit value of tensile strain and tensile modulus is proposed. Finally, prediction accuracy by FEM analysis for tensile deformation of laminated rubber bearing is verified.
\end{abstract}

Keywords : Laminated rubber bearings, Seismically isolated structure, Critical characteristic, Tensile deformation, Tensile modulus, Finite element method

積層ゴム, 免震構造, 限界特性, 引張変形, 引張弾性率, 有限要素法

\section{1. はじめに}

近年、安全・防災・BCP に対する関心の高まりにより、高さ $20 \mathrm{~m}$ を超える中高層ビルを中心に建築物の免震化が進んでいる。特に 2011 年の東北地方太平洋沖地震にて免震の効果が実証され、さらに 免震技術に対する注目が集まっている。近年では高さ $100 \mathrm{~m}$ を超え るような超高層建物の免震化も一般的となってきた。このような超 高層建物を免震化する場合、水平動による転倒モーメントの影響で、 一部の免震装置に引張が生じる場合がある。また、セットバックを 有寸る建物においても、低層部で長期荷重が小さくなるため、水平 動による転倒モーメントの影響を受けや寸く、引抜が生じることが ある。現在、日本における免震装置は積層ゴムが一般的であるが、 積層ゴムは圧縮弾性率(圧縮剛性)に対して引張弾性率(引張剛性)が 低いという特徴がある(引張剛性は引張弾性率にゴムの有効断面積 を掛け、ゴム総厚さで除すことで算出できる)。これは、積層ゴムが 鉛直方向に引張を受けた際に、ゴム内部にボイドが発生し、剛性が 低下寸ることに起因する ${ }^{1)}$, 2)。このため、兔震構造物を設計する場 合、積層ゴムに過度な引張力が生じないようにする必要がある。こ の場合の積層ゴムの引張限界は引張限界応力として規定され、その
限界応力は積層ゴムの種類によらず、一律 $1 \mathrm{MPa}$ と規定されている のが現状である。一方、転倒モーメントにより一部の積層ゴムに引 張が生じると、圧縮剛性に比べて引張剛性が格段に低いことから負 担軸力が減少し、引張が生じた積層ゴムから周辺の積層ゴムに軸力 が移動する、軸力の再配分が行われる。その際上部構造には、軸力 の再配分に対応できる剛性と耐力が必要となる。引張面圧を $1 \mathrm{MPa}$ に留めることで、再配分に対する上部構造への影響を小さく抑えて いると考えられる。設計の際に積層ゴムに $1 \mathrm{MPa}$ を超える引張が生 じる恐れがある場合、(1)高い引張限界強度を有する免震装置の使用、 (2)積層ゴムに $1 \mathrm{MPa}$ 以上の引張が生じない特殊な構造の採用の 2 通 りが考えられる。前者は、リニアスライダー等を活用したものが提 案されており 3)、高い引張限界強度を有する積層ゴムの利用に関す る研究もなされている ${ }^{4)}$ 。後者についてはこれまでに数多くの機構 が考案されており、実用化されているものも多い例えば5),6),7), 8)。

このように積層ゴムの引張限界を引張応力で規定した場合、積層 ゴムに $1 \mathrm{MPa}$ 以上の引張が生じるケースがしばしば発生し、免震設 計の際の過度な制約条件となっている。そこで、引張に対する過度 な制約を緩める方法の一つに、基準值を応力ではなくひずみによっ
*1 (株ブリヂストンインフラ資材開発部 博士(理学)

*2 (株ブリヂストンインフラ資材開発部 博士 (工学)

*3 (株)ブリヂストンインフラ資材開発部 Ph.D.

*4 東京理科大学理工学部建築学科 教授 · 博士 (工学)

*5 東京理科大学理工学部建築学科 助教 · 博士 (工学)
Infrastructure Products Development Dept. Bridgestone Co., Dr.Sci.

Infrastructure Products Development Dept., Bridgestone Co., Dr.Eng.

Infrastructure Products Development Dept., Bridgestone Co., Ph.D

Prof., Dept. of Architecture, Tokyo Univ. of Science, Dr.Eng.

Assist. Prof., Dept. of Architecture, Tokyo Univ. of Science, Dr.Eng. 
て規定することが挙げられる。積層ゴムは鋁直引張に弱いと述べた が、圧縮弾性率に対する引張弾性率が小さいのみであり、積層ゴム は鉛直引張変形に対し、高い変形能力を有していることも事実であ る 9)。そこで、引張特性を適切に評価し、引張限界を引張限界ひず みで規定することで、現行の引張限界応力一律 $1 \mathrm{MPa}$ という制約を 緩和寸ることが可能になる。ただし、一部の積層ゴムに引張が生じ ることによる積層ゴムの負担軸力の再配分と積層ゴムの引張ひずみ 量を適切に評価できる解析を行うことが前提となる。応力からひず みに限界值の規定を変えて、免震構造物を設計することにより、特 殊な構造を採用することなく免震化が可能となり、設計自由度も増 すメリットがある。

このような背景の下、本研究では積層ゴムの引張限界を従来の引 張限界応力ではなく、引張限界ひずみで規定することを目的とする。 そのためには、引張限界ひずみと引張弾性率を適切に規定する必要 があり、積層ゴムの各種引張特性の評価を実施した。その評価結果 をもとに積層ゴムが許容できる引張限界ひずみ及び引張弾性率を規 定する方法を提案した。

一般に、高軸力、大変形の必要な積層ゴムの実験評価には多大な 労力を要する。これらの労力を軽減するための手法として、FEM 解 析による予測が挙げられる。過去、著者らは積層ゴムの挙動を予測 する為のゴムの材料モデルを提案した ${ }^{10)}, 11$ 。そその中で、積層ゴムの 引張特性を予測するゴムの材料モデルも提案しており ${ }^{12}$ 、いくつか の適用例もある ${ }^{13)}$, 14)。本研究では、過去に提案した解析モデルを用 いて、積層ゴムの引張弾性率の各種依存性をどの程度予測できるか の検討も行った。

本論文の構成は以下の通りである。2 章では、実施した積層ゴム の引張実験の概要について、3 章でその実験結果を述べる。4 章で 実験結果をもとに積層ゴムの引張限界ひずみと引張弾性率の考え方 をまとめる。5 章では本研究の FEM による予測精度について述べ る。最後に 6 章で、本研究の結論をまとめる。

\section{2. 実験概要}

本章において、引張限界ひずみおよび引張弾性率の基準值を決め るための評価試験の概要を述べる。本研究では、せん断弾性率 $\mathrm{G}=0.392 \mathrm{MPa}$ の天然ゴム系積層ゴム ${ }^{15}$ (以下、NRB)を対象に一連の評 価を行った。

\section{1 試験体}

3 体の実大試験体(ゴム外径 $600 \mathrm{~mm} 、 800 \mathrm{~mm} 、 1000 \mathrm{~mm}$ )および 15 体の縮小試験体(ゴム外径 $225 \mathrm{~mm} 、 158 \mathrm{~mm}$ )を用いて引張特性の各種 依存性を評価した。試験体一覧表を表 1 に、試験体の一例として、 No.7〜14 の試験体図面の例を図 1 に示す。

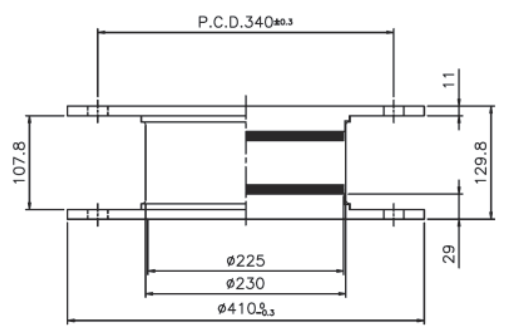

図 1 試験体の一例 (試験体 No. 7〜 14)

\section{2 試験条件}

積層ゴムに基準となるオフセットせん断ひずみ $\gamma_{\text {offset }}$ を与えた状 態から、基準となる引張ひずみ $\varepsilon$ を 1 サイクル与えた前後で、基本 性能や限界性能に影響が無いことを実大試験体にて評価した。また、 引張特性の「フランジ厚さ依存性(表 3)」、 2 次形状係数 $\mathrm{S}_{2}$ 依存性(表 4)」、「オフセットせん断ひずみ依存性(表 5)」、「繰返し依存性(表 6)」 の各種依存性を評価した。また、引張の発生が経年変化後の破断性 能に影響することが懸念される。そこで、引張発生後に経年変化し た場合と、経年変化した後に引張が発生した場合に、破断性能へ与 える影響(表 7)を評価した。積層ゴムの経年変化の評価は、通常、熱 劣化促進試験にて評価する。本研究における評価も熱劣化促進試験 を用いた。表 7 中の No.17、18 は No.15、16 に対するリファレンス 用試験である。引張後の剛性低下が、引張によるものか、オフセッ ト変形の影響によるものかを評価したリファレンス試験(表 8)も実 施した。

本研究におけるオフセットせん断ひずみおよび引張ひずみは、そ れぞれ $\gamma_{\text {offset }}=250 \% 、 \varepsilon=15 \%$ 基本とした。それぞれの值の根拠であ るが、 $\gamma_{\text {offset }}=250 \%$ は、レベル 2 地震に相当するクライテリアとして 採用した。また、 $\varepsilon=15 \%$ にいては、後述する試験結果からもわか るように、 $\gamma_{\mathrm{offset}}=250 \%$ の時の引張破断ひずみはおよそ $75 \%$ である。 圧縮限界強度は圧縮破壊のおよそ $1 / 10$ として決めており、同様に考 えると $\gamma_{\text {offset }}=250 \%$ の時の引張破断ひずみの $1 / 10$ はおよそ $7.5 \%$ とな る。ただし、今回は安全側の評価を目的に、その 2 倍の引張ひずみ $\varepsilon=15 \%$ を採用した。

評価項目および試験条件を表 2〜8 に示す。表 2〜8 に示した各試 験条件の詳細については以下のとおりである。全ての試験体で水平 基本性能試験を実施しているが、ここでは本論文中でデータを示し た試験と試験体に損傷を与える可能性のある試験のみを表 2〜8に 明記した。

\section{水平基本性能試験}

試験体を $20^{\circ} \mathrm{C}$ で保温したのち、基準面圧下でせん断ひずみ $100 \%$ の 水平加力を 3 サイクル与える。縮小試験体においては動的に加振

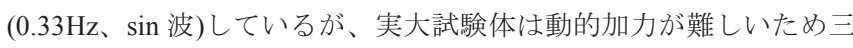
角波で静的に加振している。水平剛性は、水平基本性能試験の結果 から算出する。水平剛性は加力速度の影響が小さいため、速度補正 はしていない。

\section{鉛直基本性能試験}

オフセットひずみ $0 \%$ 下で、基準面圧 $\sigma_{\mathrm{s}} \pm 30 \%$ を静的に 3 サイクル与 える。鉛直剛性は、鉛直基本性能試験の結果から算出する。鉛直剛 性は加力速度の影響が小さいため、速度補正はしていない。

引張試験

面圧 0 の状態で規定のオフセットせん断ひずみを与えた後で、 1 サ イクル周期 10 秒以上で静的に、規定の引張ひずみまで加力する。 引張限界試験

面圧 0 の状態で規定のオフセットせん断ひずみを与えた後で、積層 ゴムに、破断、一部破断もしくは試験機のストローク限界に至るま で鉛直引張変形を与える。

水平限界試験

基準面圧もしくは基準面圧の倍の面圧下で、静的にせん断ひずみ 400\%の加力を 1 サイクル行う。また、せん断応力一せん断ひずみに 
負勾配が生じた(座屈に至った)場合は、そこで加力を中断する。 水平破断試験

基準面圧下で、破断に至るまで静的に単調加力する。

60 年相当熱劣化試験

$20^{\circ} \mathrm{C} \times 60$ 年に相当する $90^{\circ} \mathrm{C} \times 50$ 日間、面圧 $0 \mathrm{MPa}$ 下で保管する。
なお、 $90^{\circ} \mathrm{C} \times 50$ 日は、今回の一連の評価に用いたゴムの活性化エネ ルギー $7.70 \times 10^{4} \mathrm{~J} / \mathrm{mol}$ から算出した。

オフセット変形試験

面圧 0 の状態で規定のオフセット変形を与える。

表 1 試験体一覧

\begin{tabular}{|c|c|c|c|c|c|c|c|c|}
\hline 試験体 No. & No.1 & No.2 & No.3 & No.4 & No.5 & No.6 & No.7 14 & No.15 18 \\
\hline \hline ゴム外径 $\mathrm{D}(\mathrm{mm})$ & 1000 & 800 & 600 & 225 & 225 & 225 & 225 & 158 \\
\hline ゴム内径 $(\mathrm{mm})$ & 25 & 20 & 15 & 0 & 0 & 0 & 0 & 0 \\
\hline ゴム 1 層厚さ $(\mathrm{mm})$ & 6.4 & 5.1 & 4.0 & 1.6 & 1.6 & 1.6 & 1.6 & 1.1 \\
\hline ゴム積層数 & 26 & 33 & 50 & 40 & 40 & 40 & 28 & 24 \\
\hline ゴム総厚さ $(\mathrm{mm})$ & 166.4 & 168.3 & 200.0 & 64 & 64 & 64 & 44.8 & 26.4 \\
\hline 2 次形状係数 $\mathrm{S}_{2} * 1$ & 6.06 & 4.75 & 3.00 & 3.52 & 3.52 & 3.52 & 5.02 & 5.98 \\
\hline 鋼板厚さ $(\mathrm{mm})$ & 4.4 & 4.4 & 3.1 & 1.0 & 1.0 & 1.0 & 1.0 & 0.8 \\
\hline フランジ中央厚さ $(\mathrm{mm})$ & 36.0 & 32.0 & 28.0 & 8.9 & 12.9 & 19.9 & 29.0 & 28.8 \\
\hline フランジ端部厚さ $(\mathrm{mm}) * 2$ & 28.0 & 24.0 & 22.0 & 7.0 & 11.0 & 18.0 & 11.0 & 10.0 \\
\hline フランジ外径 $(\mathrm{mm})$ & 1400 & 1150 & 900 & 410 & 410 & 410 & 410 & 250 \\
\hline ボルト穴 P.C.D. $(\mathrm{mm})$ & 1250 & 1000 & 775 & 340 & 340 & 340 & 340 & 220 \\
\hline 被覆ゴム厚さ $(\mathrm{mm})$ & 8.0 & 8.0 & 8.0 & 2.5 & 2.5 & 2.5 & 2.5 & 2.0 \\
\hline 水平剛性基準値 $(\mathrm{kN} / \mathrm{mm}) * 3$ & 1.86 & 1.17 & 0.554 & 0.244 & 0.244 & 0.244 & 0.348 & 0.291 \\
\hline 鉛直剛性基準值 $(\mathrm{kN} / \mathrm{mm}) * 4$ & 4690 & 2940 & 1370 & 592 & 592 & 592 & 846 & 714 \\
\hline 基準面圧 $\sigma_{\mathrm{s}}(\mathrm{MPa})$ & 15.0 & 13.0 & 6.0 & 7.8 & 7.8 & 7.8 & 15.0 & 15.0 \\
\hline
\end{tabular}

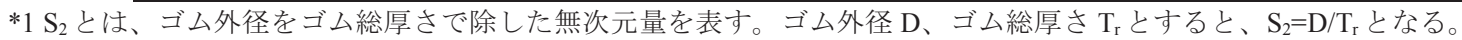

*2 以後、フランジ厚と表現した場合は、フランジ端部厚さのことを指す。

*3 基準值は、温度 $20^{\circ} \mathrm{C}$ 、せん断ひずみ $\gamma=100 \%$ 、周波数 $f=0.33 \mathrm{~Hz}$ (正弦波)で 3 サイクル水平加力した 3 サイクル目の水平剛性で規定する。

*4 基準值は、基準面圧 $\sigma_{\mathrm{s}} \pm 30 \%$ 三角波で静的に 3 サイクル鉛直加力した 3 サイクル目の鉛直剛性で規定する。

\section{表 2 実大試験体による引張前後での基本性能比較および} 引張後の限界特性評価

\begin{tabular}{|c|c|c|}
\hline 試験体 & $\begin{array}{c}\text { ゴム外径 } \\
(\mathrm{mm})\end{array}$ & 評価項目・評価順序 \\
\hline No.1 & 1000 & \multirow{3}{*}{ 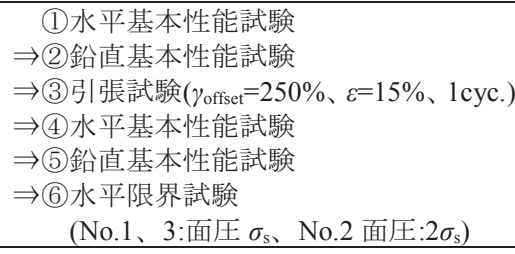 } \\
\hline No.2 & 800 & \\
\hline No.3 & 600 & \\
\hline
\end{tabular}

表 3 フランジ厚さ依存性の評価条件

\begin{tabular}{|c|c|l|}
\hline 試験体 & フランジ厚 $(\mathrm{mm})$ & \multicolumn{1}{|c|}{ 評価項目 } \\
\hline \hline No.4 & 7 & \multirow{2}{*}{$\begin{array}{l}\text { 引張試験 } \\
\left(\gamma_{\text {offset }}=250 \% 、 \varepsilon=15 \% 、 1 \mathrm{cyc} .\right)\end{array}$} \\
\hline No.5 & 11 & \\
\hline No.6 & 18 & \\
\hline
\end{tabular}

表 42 次形状係数 $S_{2}$ 依存性の評価条件

\begin{tabular}{|c|c|l|}
\hline 試験体 & 2 次形状係数 $\mathrm{S}_{2}$ & \multicolumn{1}{|c|}{ 評価項目 } \\
\hline \hline No. 5 & 3.52 & 引張試験 \\
\hline No.7 & 5.02 & $\left(\gamma_{\text {offset }}=250 \% 、 \varepsilon=15 \% 、 1 \mathrm{cyc}.\right)$ \\
\hline
\end{tabular}

表 5 オフセットせん断ひずみ依存性の評価条件

\begin{tabular}{|c|c|c|}
\hline 試験体 & オフセットせん断ひずみ & 評価項目・評価順序 \\
\hline \hline No.8 & $0 \%$ & \\
\cline { 1 - 1 } No.9 & $150 \%$ & (1)水平基本性能試験 \\
No.10 & $250 \%$ & $\Rightarrow$ (2)張限界試験 \\
No.11 & $300 \%$ & 水平基本性能試験 \\
\hline No.12 & $400 \%$ & \\
\hline
\end{tabular}

表 6 繰返し引張特性の評価条件

\begin{tabular}{|c|c|}
\hline 試験体 & 評価項目 \\
\hline \hline No.13 & 引張試験 $\left(\gamma_{\text {offset }}=250 \% 、 \varepsilon=15 \% 、 20 \mathrm{cyc}\right.$. $)$ \\
\hline
\end{tabular}

表 7 経年変化の評価条件

\begin{tabular}{|c|c|}
\hline 試験体 & 評価項目・評価順序 \\
\hline No.15 & $\begin{aligned} & \text { (1)引張試験 }\left(\gamma_{\text {offset }}=250 \% 、 \varepsilon=15 \% 、 1 \mathrm{cyc} .\right) \\
& \Rightarrow(2) 60 \text { 年相当熱劣化試験 } \\
&\left.\Rightarrow \text { (3)水平破断試験(面圧: } \sigma_{\mathrm{s}}\right)\end{aligned}$ \\
\hline No.16 & $\begin{array}{l}\Rightarrow \text { (1)60 年相当熱劣化試験 } \\
\Rightarrow \text { (2)引張試験 }\left(\gamma_{\mathrm{offset}}=250 \% 、 \varepsilon=15 \% 、 1 \mathrm{cyc} \text {.) }\right. \\
\left.\Rightarrow \text { (3)水平破断試験(面圧: } \sigma_{\mathrm{s}}\right)\end{array}$ \\
\hline No.17 & $\begin{aligned} & \text { (1)引張試験 }\left(\gamma_{\mathrm{offse}}=250 \% 、 \varepsilon=15 \% 、 1 \mathrm{cyc} .\right) \\
&\left.\Rightarrow(2) \text { 水平破断試験(面圧: } \sigma_{\mathrm{s}}\right)\end{aligned}$ \\
\hline No.18 & (1)水平破断試験(面圧: $\sigma_{\mathrm{s}}$ ) \\
\hline
\end{tabular}

表 8 リファレンス試験の評価条件

\begin{tabular}{|c|c|}
\hline 試験体 & 評価項目 - 評価順序 \\
\hline No.7 & $\begin{aligned} & \text { (1)水平基本性能試験 } \\
& \Rightarrow \text { (2)引張試験 }\left(\gamma_{\text {offset }}=250 \% 、 \varepsilon=15 \% 、 1 \mathrm{cyc} .\right) \\
& \Rightarrow \text { (3)水平基本性能試験 }\end{aligned}$ \\
\hline No.14 & $\begin{aligned} & \text { (1)水平基本性能試験 } \\
&\left.\Rightarrow \text { (2)オフセット変形試験(引張無しで } \gamma_{\text {offset }}=250 \%\right) \\
& \Rightarrow \text { (3)水平基本性能試験 }\end{aligned}$ \\
\hline
\end{tabular}

\section{3. 実験結果}

本章では、2 章に示した実験の評価結果を述べる。

3. 1 引張試験前後での基本性能変化と水平限界性能への影響 実大試験体(ゴム外径 $600 \mathrm{~mm} 、 800 \mathrm{~mm} 、 1000 \mathrm{~mm}$ )を用い、積層ゴ 
ムに引張ひずみ $15 \%$ の引張を与えた前後での基本性能の変化や、水 平限界特性への影響を評価した結果を以下に示す。

表 9 に引張を与えた前後での基本性能の変化を、図 2 に各加力試 験におけるせん断応力一せん断ひずみ曲線および引張応力一引張ひ ずみ曲線の結果を示す。表 9 及び図 2 からわかるように、引張変形 を与える前後で、基本性能一の影響は水平剛性で-5 -6\%程度、鉛直 剛性で $\pm 3 \%$ 以内であり、引張ひずみ $15 \%$ の張の影響が小さいこと がわかる。また、リファレンス試験の結果を表 10 に示した。試験体 No.7は、表 8 に示した通り、水平基本性能 $\Rightarrow$ オフセット $250 \%$ の引 張試験 $\Rightarrow$ 水平基本性能の順に試験を行い、No.14 は水平基本性能 $\Rightarrow$ オフセット $250 \%$ で引張無し $\Rightarrow$ 水平基本性能の順で試験した。表 10 の結果から、積層ゴムに引張を与えなくても、オフセット $250 \%$ の せん断変形を与えるだけで-5.8\%の水平剛性の低下がみられる。よっ て、表 9 で示したような引張変形後の水平剛性の低下は、引張の影
響ではなく、オフセットせん断の影響の方が大きいことがわかる。

図 3 には圧縮限界強度線図を示した。圧縮限界強度線図は、主に 2 次形状係数 $\mathrm{S}_{2}$ によって定まり、ゴム種ごとに規定された限界線図 であり、縦軸に圧縮面圧を、横軸にせん断ひずみをとり、各せん断 ひずみに対する限界圧縮面圧、あるいは各圧縮面圧に対する限界せ ん断ひずみを規定した図である。図 3 の圧縮限界強度線図上に、引 張ひずみ $15 \%$ の張を与えた後に行った水平限界試験結果をプロッ トした。即ち、今回の実験における積層ゴムの面圧と座屈が生じた ひずみをプロットしている。×は実験において座屈が生じた瞬間の せん断ひずみであり、○は座屈が生じなかったため実験で加力した 最大せん断ひずみの值を表す。いずれの試験も圧縮限界強度線図内 で座屈が生じていないことがわかる。このことから、引張ひずみ $15 \%$ の引張を与えても、求められる水平限界特性を有していることがわ かる。
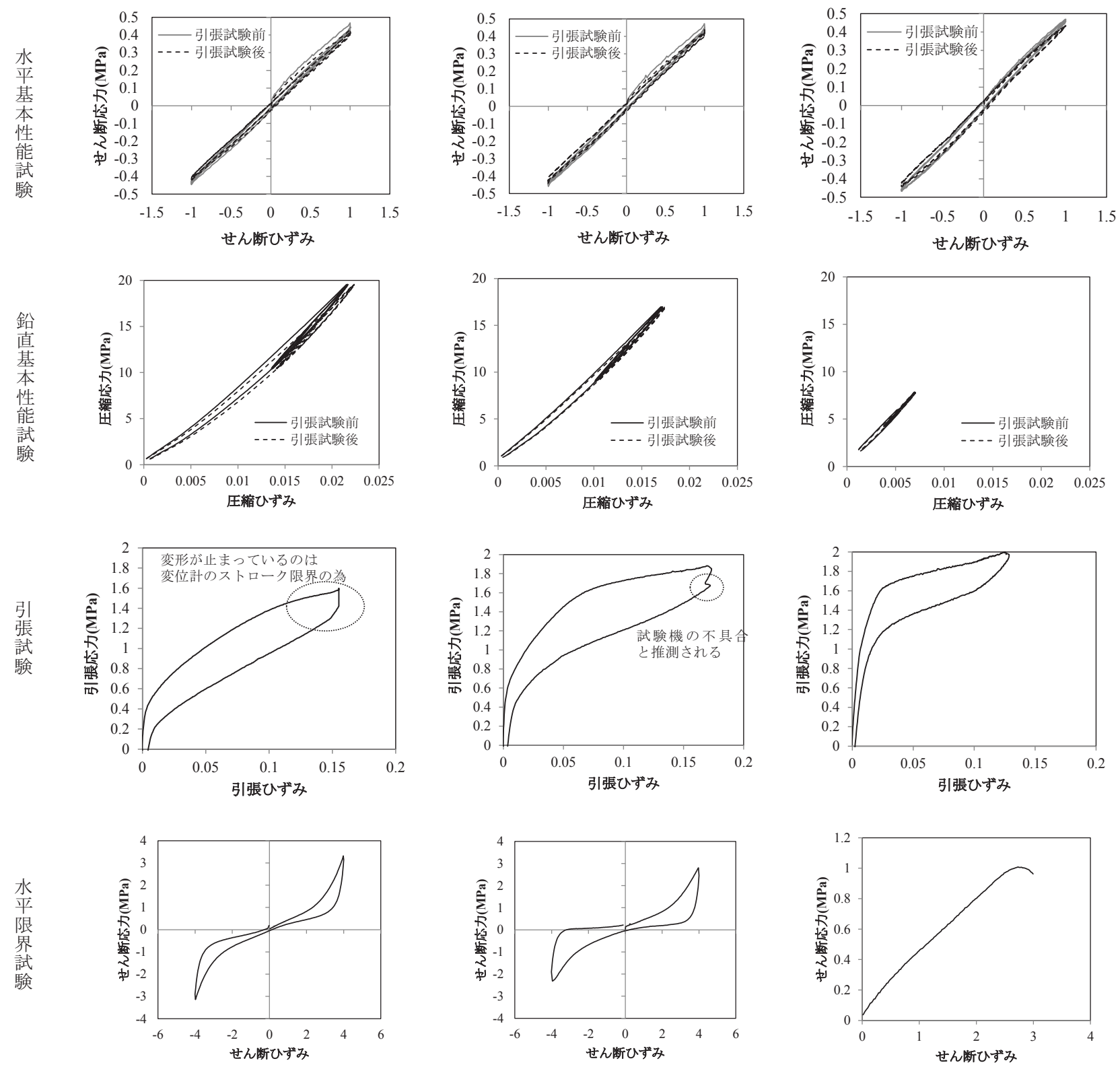

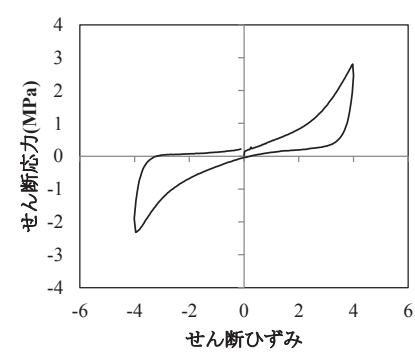

試験体 No.2( $(\varphi 800)$

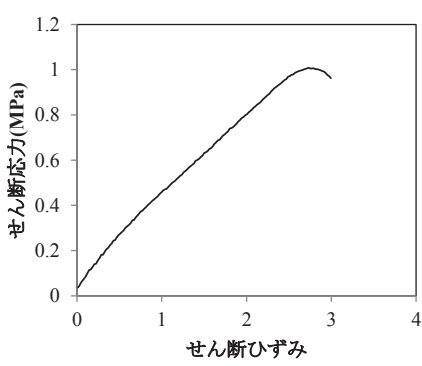

試験体 No.3( $(9600)$

試験体 No.1 $(\varphi 1000)$

図 2 実大試験におけるせん断応カーせん断ひずみ曲線及び引張応カー引張ひずみ曲線 


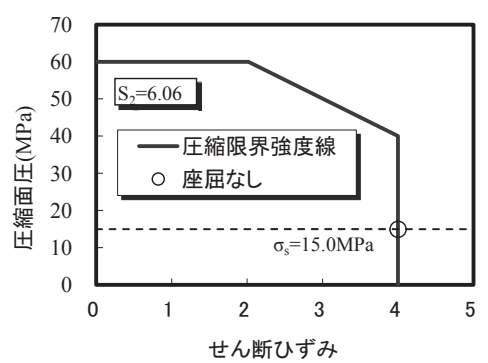

試験体 No.1( $(\varphi 1000)$

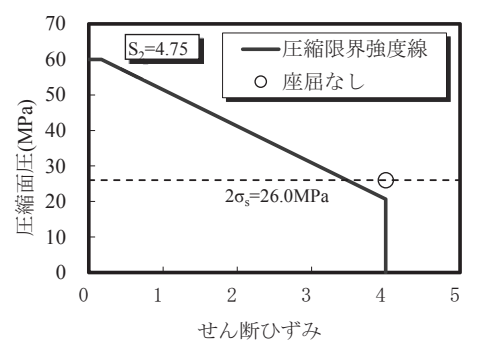

試験体 No.2( $(\varphi 800)$

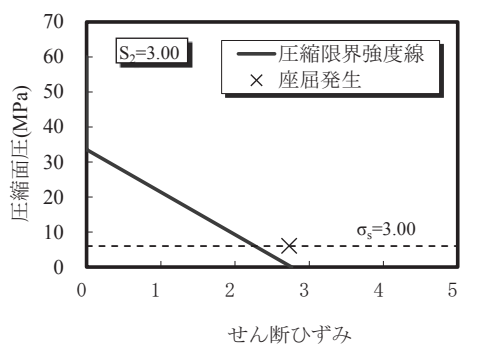

試験体 No.3( $(600))$

図 3 圧縮限界強度線図と水平限界試験の比較

表 9 実大試験における基本性能試験の結果 (水平基本性能試験、鉛直基本性能試験)

\begin{tabular}{|c|c|c|c|c|c|c|}
\hline & \multicolumn{2}{|c|}{ 試験体 No.1( $(\varphi 1000)$} & \multicolumn{2}{|c|}{ 試験体 No.2( $(\varphi 800)$} & \multicolumn{2}{|c|}{ 試験体 No.3( $(\varphi 600)$} \\
\hline & 引張試験前 & 引張試験後 & 引張試験前 & 引張試験後 & 引張試験前 & 引張試験後 \\
\hline 水平剛性 $(\mathrm{kN} / \mathrm{mm})$ & 2.093 & 1.985 & 1.340 & 1.273 & 0.655 & 0.616 \\
\hline 水平剛性基準値 $(\mathrm{kN} / \mathrm{mm})$ & \multicolumn{2}{|c|}{1.86} & \multicolumn{2}{|c|}{1.17} & \multicolumn{2}{|c|}{0.554} \\
\hline 対基準値(\%) & +12.3 & +6.5 & +14.5 & +8.8 & +18.3 & +11.2 \\
\hline 引張試験前後での変化率(\%) & \multicolumn{2}{|c|}{-5.2} & \multicolumn{2}{|c|}{-5.0} & \multicolumn{2}{|c|}{-6.0} \\
\hline 鉛直剛性(kN/mm) & 5431 & 5336 & 3400 & 3350 & 1596 & 1630 \\
\hline 鉛直剛性基準値(kN/mm) & \multicolumn{2}{|c|}{4690} & \multicolumn{2}{|c|}{2940} & \multicolumn{2}{|c|}{1370} \\
\hline 対基準値(\%) & +15.8 & +13.8 & +15.6 & +13.9 & +16.5 & +19.0 \\
\hline 引張試験前後での変化率(\%) & \multicolumn{2}{|c|}{-1.7} & \multicolumn{2}{|c|}{-1.5} & \multicolumn{2}{|c|}{+2.1} \\
\hline
\end{tabular}

表 10 縮小試験体によるリファレンス試験の結果 (水平基本性能試験)

\begin{tabular}{|c|c|c|c|c|}
\hline \multirow{2}{*}{} & \multicolumn{3}{|c|}{ 試駚体 No.7 $(\varphi 225)$} & \multicolumn{2}{|c|}{ 試駚体 No.14 $(\varphi 225)$} \\
\cline { 2 - 5 } & 引張試験前 & 引張試験後 & 引張試験前 & 引張試験後 \\
\hline \hline 水平剛性 $(\mathrm{kN} / \mathrm{mm})$ & 0.378 & 0.359 & 0.379 & 0.356 \\
\hline 水平剛性基準值值 $(\mathrm{kN} / \mathrm{mm})$ & \multicolumn{3}{|c|}{0.348} & +2.7 \\
\hline 対基準值 $(\%)$ & +8.7 & +2.2 & +9.0 & +5.8 \\
\hline 引張試験前後での変化率 $(\%)$ & \multicolumn{3}{|c|}{-6.0} \\
\hline
\end{tabular}

\section{2 引張弾性率の各種依存性の評価}

積層ゴムの限界ひずみで免震建物を設計する場合、安全側の評価 となるよう、適切に引張弾性率を規定する必要がある。引張弾性率 を規定する為に、引張弾性率の各種依存性を評価した。本研究で考 慮した依存性は、「フランジ厚さ依存性」、「2 次形状係数依存性」、「才 フセットせん断ひずみ依存性」「繰返し依存性」の 4 項目とした。 表 3〜6 に示した様々な条件で引張試験を行い、引張弾性率の依存性 を調べた。

各依存性の結果を図 4〜7 に示す(ここでは、FEM 解析の結果もプ ロットしているが、解析結果との比較に関しては、5 章で論じる)。 なお、オフセットせん断ひずみ依存性における引張試験は、引張限 界試験であるため、全ひずみ領域と、小ひずみ領域を拡大した図を 示した。ただし、オフセットせん断ひずみ $0 \%$ と $150 \%$ では、試験機 のストローク限界まで引張を与えても破断もしくは一部破断が生じ なかったため、ストローク限界である引張ひずみ $160 \%$ までの引張 応力ー引張ひずみ関係を示した。オフセット $250 \% 、 300 \% 、 400 \%$ で は一部破断が生じた際に試験を終了した。オフセット $250 \%$ での引 張限界試験において、積層ゴムに一部破断発生後の引張ひずみ $75 \%$ 時の様子を図 8 に示した。

図 4、5 の結果から、2 次形状係数が大きい程、また、フランジ厚
さが厚い程引張弾性率が高くなる傾向があることがわかる。一方、 図 6 からもわかるように、オフセットせん断ひずみ依存性について は振る舞いが複雑である。引張ひずみ $50 \%$ 以下の領域で、引張弾性 率はオフセット $250 \%$ まではオフセットせん断ひずみが大きい程引 張弾性率が小さくなる傾向を示す。しかし、オフセット $250 \%$ 以上 では逆にオフセットせん断ひずみが大きい程剛性が高くなる傾向を 示す。また、引張ひずみ $50 \%$ を超える領域では、オフセットせん断 ひず夕が大きい程引張弾性率が大きくなる傾向を示した。オフセッ 卜 $250 \% 、 300 \% 、 400 \%$ では一部破断が生じたが、完全な破断には至 らなかった。図 8 の写真からもわかるように、一部破断は白丸の籄 所で生じた。そのため、一部破断後も荷重支持能力を有していたた め、破断試験前後で水平基本性能試験を行い、基本性能の変化を比 較した。代表としてオフセット $0 \% 、 300 \% 、 400 \%$ の 3 体の結果を表 11 に示寸。引張による一部破断が生じた後でも積層ゴムの水平剛性 の低下は最大でも $10 \%$ 程度であり、少なくとも積層ゴムが一部破断 後も荷重支持能力を有していることがわかる。図 7 の結果より、繰 返し引張に関しては、1 サイクル目と 2 サイクル目で引張弹性率の 低下が大きいが、2 サイクル目以降では引張弾性率は安定している ことがわかる。 


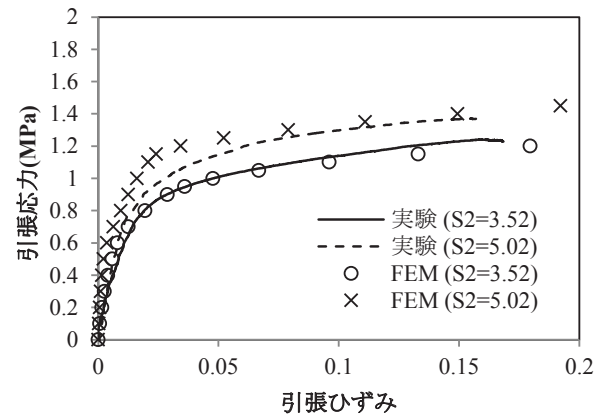

図 4 引張特性の 2 次形状係数依存性

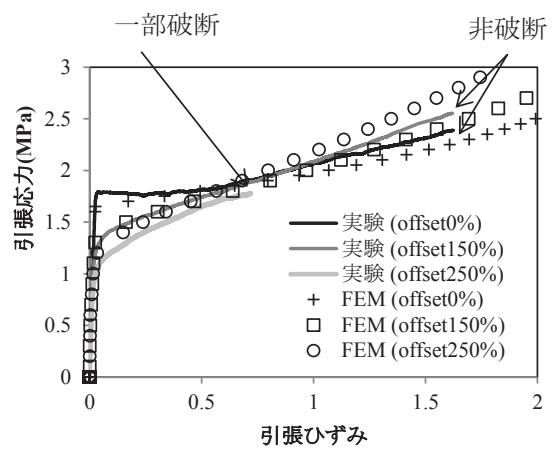

(a) 全ひずみ領域(オフセット $0,150,250 \%)$

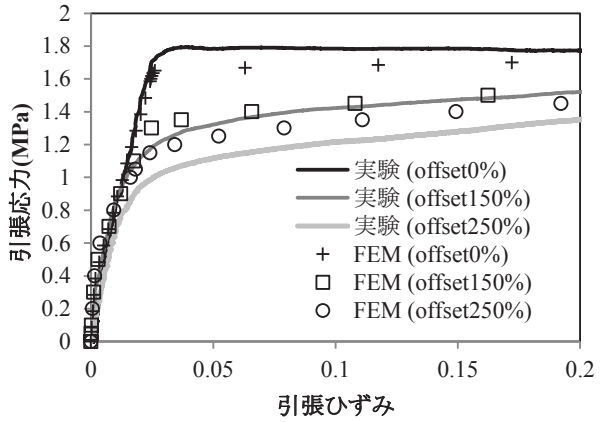

(c) 小ひずみ領域拡大(オフセット $0,150,250 \%)$

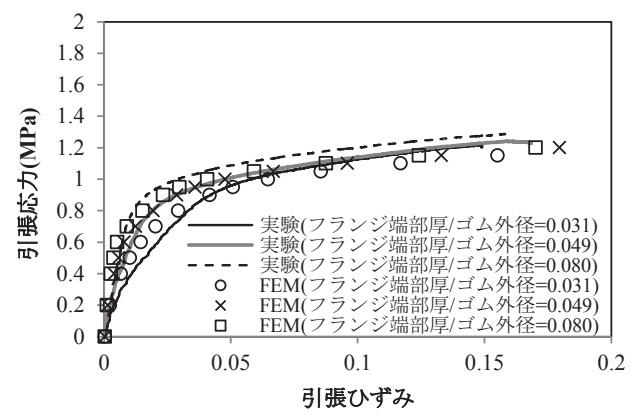

図 5 引張特性のフランジ厚さ依存性

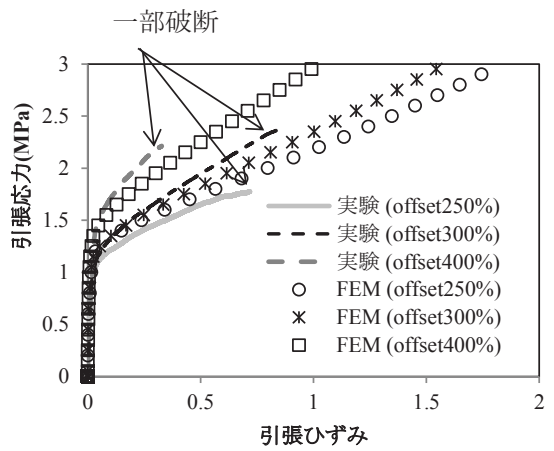

(b) 全ひずみ領域(オフセット $250,300,400 \%$ )

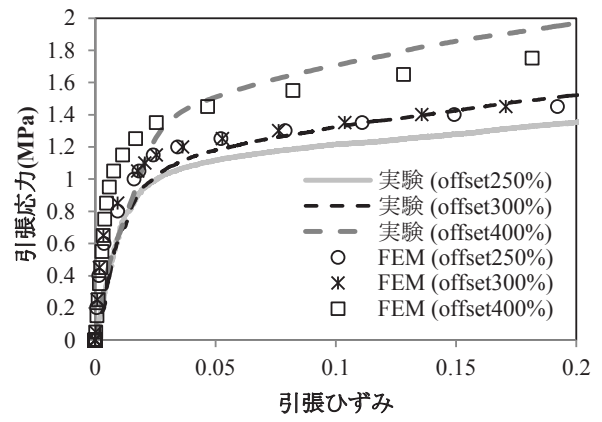

(d) 小ひずみ領域拡大(オフセット $250,300,400 \%)$

図 6 引張特性のオフセットせん断ひずみ依存性

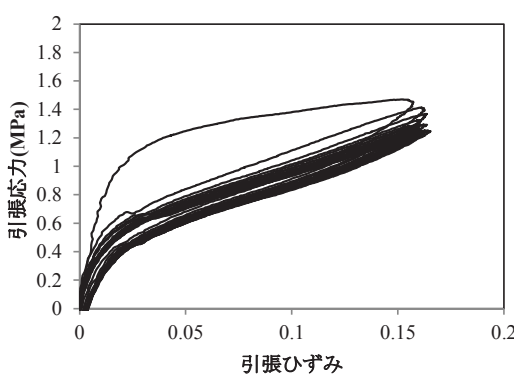

図 7 引張特性の繰返し依存性

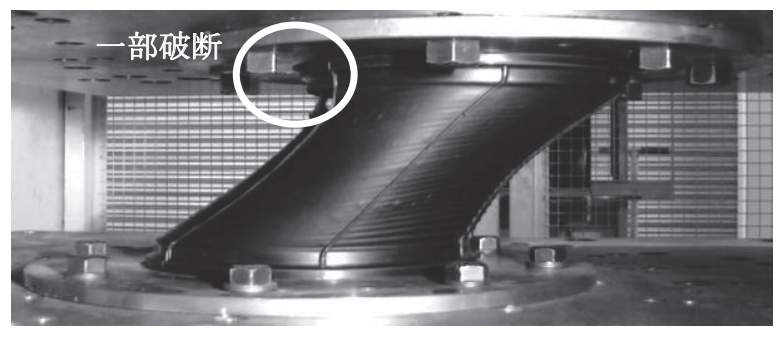

図 8 オフセット $250 \%$ 引張限界試験の一部破断(引張ひずみ: $75 \%$ )

表 11 オフセットせん断ひずみ依存試験における限界試験前後の基本性能試験の結果 (水平基本性能試験)

\begin{tabular}{|c|c|c|c|c|c|c|}
\hline & \multicolumn{2}{|c|}{ 試験体 No.8(オフセット 0\%) } & \multicolumn{2}{|c|}{ 試験体 No.11(オフセット 300\%) } & \multicolumn{2}{|c|}{ 試験体 No.12(オフセット 400\%) } \\
\hline & 引張試験前 & 引張試験後 & 引張試験前 & 引張試験後 & 引張試験前 & 引張試験後 \\
\hline 水平剛性 $(\mathrm{kN} / \mathrm{mm})$ & 0.343 & 0.328 & 0.341 & 0.310 & 0.349 & 0.309 \\
\hline 水平剛性基準值(kN/mm) & \multicolumn{6}{|c|}{0.348} \\
\hline 対基準値(\%) & -1.5 & -5.7 & -1.9 & -10.8 & +0.2 & -11.3 \\
\hline 試験前後での変化率(\%) & \multicolumn{2}{|c|}{-4.3} & \multicolumn{2}{|c|}{-9.1} & \multicolumn{2}{|c|}{-11.5} \\
\hline
\end{tabular}




\section{3 引張の発生が経年変化後の破断性能に与える影響}

引張の発生が経年変化後の破断性能に影響することが懸念される。 そこで、引張発生後に経年変化した場合と、経年変化した後に引張 が発生した場合に、破断性能へ与える影響を評価した。表 7 に示し た様々なケースで、引張や経年変化を経験した 4 体の試験体の水平 破断試験におけるせん断応力一せん断ひずみ試験の結果を図 9 に示 す。引張後に経年変化を経験した No.15 試験体と、経年変化後に引 張を経験した No.16 試験体は、経年変化を経験していない No.17、 18 試験体に対し、破断ひずみが $50 \%$ 程度低下している。これは主に 経年変化による破断ひずみの低下と考えられ ${ }^{16}$ 、引引張発生後に経年 変化した場合と、経年変化した後に引張が発生した場合共に、引張 発生が破断性能へ与える影響は小さいと言える。引張試験後に熱劣 化促進試験を実施した No.15 の試験体の破断試験後の破断面の図を 図 10 に示寸。図 10 の破断面は、引張試験時に、大きな引張が生じ た側の破断面を拡大した。目視できるボイドの発生はなかった。

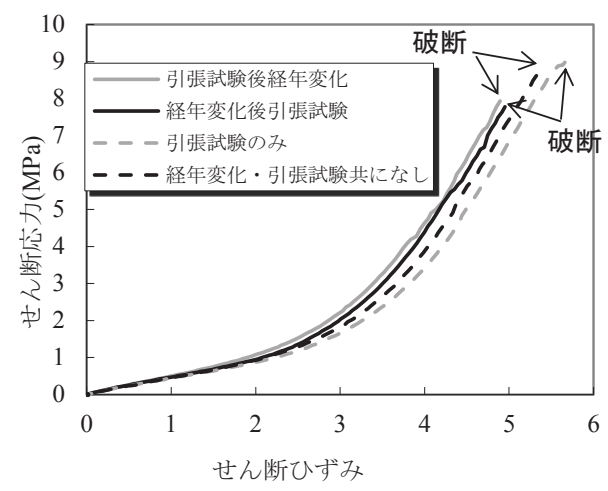

図 9 水平破断試験におけるせん断応カーせん断ひずみ曲線

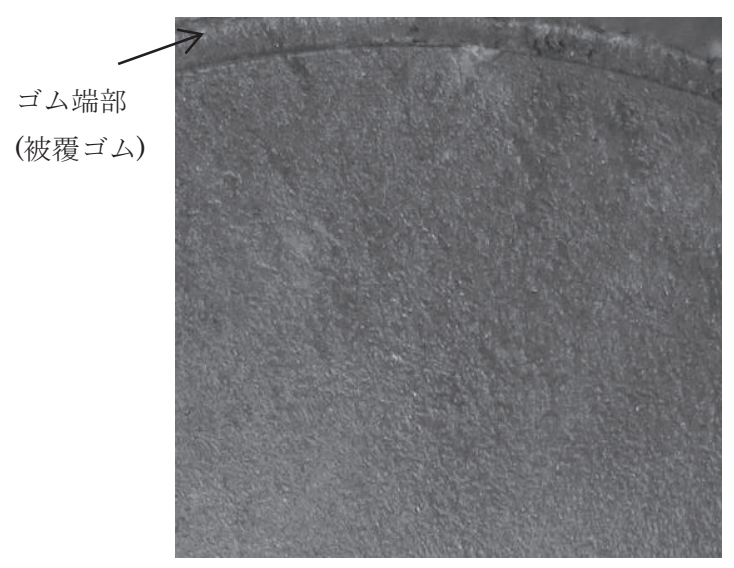

図 10 引張試験後熱劣化した試験体における破断面 （破断面の端部拡大図）

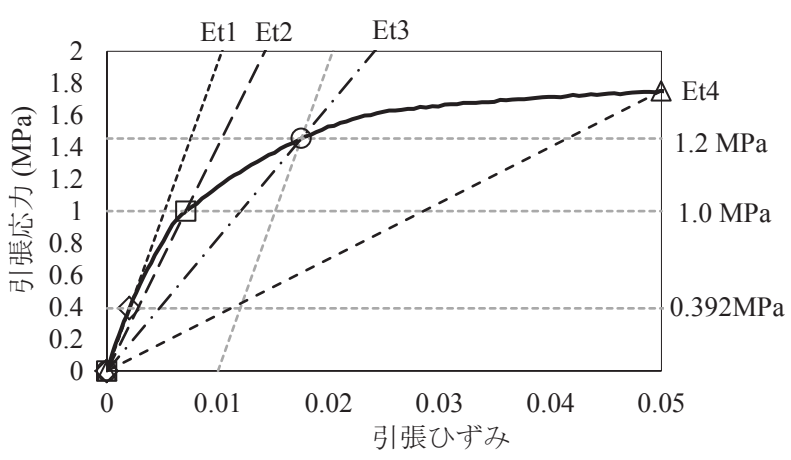

図 11 引張弾性率の算出例

表 12 引張弾性率の各種依存性評価結果一覧

\begin{tabular}{|c|c|c|c|c|c|c|c|c|c|c|c|c|c|}
\hline $\begin{array}{l}\text { 試験 } \\
\text { 体 No. }\end{array}$ & $\begin{array}{l}\text { ゴム } \\
\text { 外径 }\end{array}$ & $\begin{array}{l}\text { オフセッ } \\
\text { トせん断 } \\
\text { ひずみ }\end{array}$ & $\begin{array}{c}2 \text { 次 } \\
\text { 形状係数 }\end{array}$ & $\begin{array}{c}\text { フランジ厚/ } \\
\text { ゴム外径 }\end{array}$ & $\begin{array}{c}\text { 圧縮弾性 } \\
\text { 率(基準 } \\
\text { 值)米 }\end{array}$ & \multicolumn{4}{|c|}{ 引張弾性率 } & \multicolumn{4}{|c|}{ 圧縮弾性率(基準值)/引張弾性率 } \\
\hline- & $\mathrm{D}$ & $\gamma$ & $\mathrm{S}_{2}$ & - & $\mathrm{Ec}$ & Et1 & Et2 & Et3 & Et4 & Ec/Et1 & $\mathrm{Ec} / \mathrm{Et} 2$ & $\mathrm{Ec} / \mathrm{Et} 3$ & $\mathrm{Ec} / \mathrm{Et} 4$ \\
\hline- & $\mathrm{mm}$ & $\%$ & - & - & MPa & $\mathrm{MPa}$ & $\mathrm{MPa}$ & $\mathrm{MPa}$ & $\mathrm{MPa}$ & - & - & - & - \\
\hline 1 & 1000 & 250 & 6.06 & 0.028 & \multirow{13}{*}{953} & 113 & 21 & 41 & 20 & 8.5 & 46.4 & 23.3 & 47.1 \\
\hline 2 & 800 & 250 & 4.75 & 0.030 & & 255 & 51 & 65 & 29 & 3.7 & 18.5 & 14.7 & 32.9 \\
\hline 3 & 600 & 250 & 3.00 & 0.037 & & 193 & 140 & 83 & 35 & 4.9 & 6.8 & 11.5 & 27.2 \\
\hline 8 & 225 & $\underline{\mathbf{0}}$ & 5.02 & 0.049 & & 91 & 77 & 60 & 36 & 10.4 & 12.4 & 15.8 & 26.7 \\
\hline 9 & 225 & $\underline{150}$ & 5.02 & 0.049 & & 96 & 64 & 52 & 26 & 9.9 & 14.8 & 18.4 & 36.1 \\
\hline 10 & 225 & $\underline{250}$ & 5.02 & 0.049 & & 74 & 39 & 42 & 22 & 12.8 & 24.5 & 22.6 & 42.6 \\
\hline 11 & 225 & $\underline{300}$ & 5.02 & 0.049 & & 74 & 43 & 43 & 24 & 12.8 & 22.4 & 22.4 & 40.3 \\
\hline 12 & 225 & $\underline{400}$ & 5.02 & 0.049 & & 78 & 54 & 48 & 30 & 12.2 & 17.7 & 19.7 & 31.6 \\
\hline 5 & 225 & 250 & $\underline{3.52}$ & 0.049 & & 60 & 21 & 35 & 20 & 15.9 & 46.3 & 27.1 & 47.4 \\
\hline 7 & 225 & 250 & $\underline{5.02}$ & 0.049 & & 83 & 36 & 44 & 23 & 11.5 & 26.3 & 21.7 & 41.6 \\
\hline 4 & 225 & 250 & 3.52 & $\underline{0.031}$ & & 37 & 17 & 25 & 19 & 25.8 & 55.5 & 38.4 & 49.7 \\
\hline 5 & 225 & 250 & 3.52 & $\underline{0.049}$ & & 60 & 21 & 35 & 20 & 15.9 & 46.3 & 27.1 & 47.4 \\
\hline 6 & 225 & 250 & 3.52 & $\underline{0.080}$ & & 88 & 35 & 45 & 22 & 10.9 & 27.6 & 21.0 & 43.8 \\
\hline
\end{tabular}

※ 各パラメータ(オフセットせん断ひずみ、2 次形状係数、フランジ厚/ゴム外径)の依存性を評価した值を、太字で示した。 ※ 圧縮弾性率の基準值 $\mathrm{Ec}$ は、一連の評価の中で $\mathrm{S}_{1}$ の最も小さい $\mathrm{Ec}$ の試験体 No.4〜14 の值を用いた。 
表 13 繰返し試験における引張弾性率の変化 (試験体 No. 13)

\begin{tabular}{|c|c|c|c|c|c|c|c|c|c|}
\hline 繰返し & 圧縮弹性率(基準値)米 & \multicolumn{4}{|c|}{ 引張弾性率 } & \multicolumn{4}{|c|}{ 圧縮弾性率(基隻値)/引張弾性率 } \\
\hline $\mathrm{N}$ & $\mathrm{Ec}$ & Et1 & Et2 & Et3 & Et4 & $\mathrm{Ec} / \mathrm{Et} 1$ & Ec/Et2 & Ec/Et3 & $\mathrm{Ec} / \mathrm{Et} 4$ \\
\hline cyc. & $\mathrm{MPa}$ & $\mathrm{MPa}$ & $\mathrm{MPa}$ & $\mathrm{MPa}$ & $\mathrm{MPa}$ & - & - & - & - \\
\hline 1 & \multirow{6}{*}{953} & 94 & 51 & 49 & 25 & 10.1 & 18.6 & 19.5 & 38.1 \\
\hline 2 & & 52 & 13 & 29 & 17 & 18.3 & 73.0 & 32.6 & 55.9 \\
\hline 3 & & 45 & 11 & 26 & 16 & 21.2 & 83.8 & 36.4 & 58.7 \\
\hline 5 & & 43 & 10 & 25 & 16 & 21.9 & 91.9 & 37.6 & 61.3 \\
\hline 10 & & 37 & 9 & 23 & 15 & 25.5 & 101.1 & 41.7 & 64.7 \\
\hline 20 & & 33 & 9 & 21 & 14 & 29.0 & 110.0 & 45.6 & 68.4 \\
\hline
\end{tabular}

※ 圧縮弾性率の基準值 $\mathrm{Ec}$ は、一連の評価の中で $\mathrm{S}_{1}$ の最も小さい $\mathrm{Ec}$ の試験体 No.4〜 14 の值を用いた。

\section{4. 引張限界ひずみおよび引張弾性率の提案}

本章では、3 章で得られた結果から、今回評価したせん断弾性率 $G=0.392 \mathrm{MPa}$ を持つ NRB の引張限界ひずみおよび引張弾性率の規定 例を示す。

引張限界ひずみ

3 章でも述べたとおり、積層ゴムの健全性を、様々な形状の下、 オフセットせん断ひずみ $250 \%$ で引張ひずみ $15 \%$ 与えた後で、水 平基本性能、鉛直基本性能、限界特性等を調べ、性能に問題が無い ことを確認した。引張限界ひずみの規定には、更に安全を見る必要 があると考えられる。本論文では、15\%に 3 倍の安全率を見て、引 張限界ひずみとして $5 \%$ を提案する。

引張弾性率

引張弾性率の提案を目的に、3 章で示した各依存性試験において、 引張弾性率を算出した。引張弾性率の算出方法に関しては特に統一 された規定がないため、引張弾性率については、以下の 4 種の弾性 率を算出した。

(1)Et1 : 引張応力ー引張ひずみ曲線の「原点」と「引張応力がせん 断岡性 $(=0.392 \mathrm{MPa})$ と等しくなる点」を結ぶ直線の傾き。

(2)Et2 : 引張応力ー引張ひずみ曲線の「原点」と「引張応力が引張 限界応力 $(=1.0 \mathrm{MPa})$ と等しくなる点」を結ぶ直線の傾き。

(3)Et3 : 引張応力ー引張ひずみ曲線の「原点」と「大鳥ら提案の方 法 ${ }^{17)}$ で求めた引張限界応力と等しくなる点」を結ぶ直線の 傾き。

(4)Et4 : 引張応力ー引張ひずみ曲線の「原点」と「引張限界ひずみ $5 \%$ と等しくなる点」を結ぶ直線の傾き。

各種引張弾性率の算出例を図 11 に、引張弾性率の算出結果を表 12 に示す。引張ひずみの大きい領域で規定される Et4 が、引張弾性率 が最も低くなる傾向を示すことがわかる。引張限界值を、限界ひず みで規定する場合、引張による積層ゴム軸力の再配分と引張ひずみ 量を適切に評価できる解析を行うことが必要になり、その解析から 求まる再配分軸力と引張ひずみは、引張弾性率が小さい方が安全側 の評価となるため、Et4 の值を用いて設計すべきであると考えられ る。図 7 より繰返し加力で Et4 が低下寸ることが確認されている。 しかしながら、引張限界ひずみ $5 \%$ を限とした $5 \%$ 以内の繰返し引 張では、Et4 の低下は小さいと考えられる。これは、積層ゴムの引 張特性が Mullin's 効果 ${ }^{18}$ に似た振る舞いを示寸ことが知られている からである。即ち、一度ある最大引張ひずみまで引張りを与えた後 一度ひずみ 0 まで戻し、再び一度目と同じ最大引張ひずみまで変形
を与えると、最大引張ひずみに至るまでの過程では剛性が低下寸る が、最大引張ひずみ到達時には一度目とほぼ同じ応力状態に達する 例えば 15), 19)の実脸データ。図 7 からもわかるように、引張ひずみ $5 \%$ を結ぶ 直線の引張弾性率は一度目に比べて二度目以降剛性が大きく低下す るが、最大引張ひずみである $15 \%$ を結ぶ直線の引張弾性率の低下が 小さいことがわかる。よって、引張ひずみ $5 \%$ 以下の繰返しであれ ば、上記の (4)で定義した Et4 の低下はほとんどないと考えられる。

表 12 より Et4 は概ね圧縮弾性率 Ec の 1/50 を上回っている。よっ て、引張弾性率は圧縮弾性率の $1 / 50$ 以下を提案寸る。表 13 の引張 ひずみ $15 \%$ の繰返し試験においては、圧縮弾性率 Ec に対する引張 弾性率の比率 Et $4 / \mathrm{Ec}$ が 1/50 以下になることはあるが、上述したよ うに、基準值である引張限界ひずみ $5 \%$ 以内の繰返し引張では、 2 サ イクル目以降の剛性の低下は小さい。よって、引張弾性率を圧縮弾 性率 Ec の 1/50 以下と規定するのは妥当と考えられる。試験結果か らもわかるように、引張応力 -引張ひずみ特性は曲線であり、それ を直線で規定している点も、安全側の引張弾性率となっている。な お、1。はじめにで述べたように、引張限界を引張ひずみで規定す る際に、上部構造の設計の前提となる積層ゴムの負担軸力の再配分 と引張ひずみ量を適切に評価できる解析に用いることを想定して、 引張弾性率を規定している。ただし、積層ゴム取付ボルトの設計な ど、積層ゴムに生じる引張応力に基づき部材の設計を行う場合には、 危険側の評価となる可能性があり、表 12 に示した引張弾性率の結 果から適切な值を設定する必要がある。

\section{5. 過去に提案されたFEM 解析モデルの検証}

$2 、 3$ 章で示した評価には実験に多大な評価項目を要する。これ らの評価を軽減するための手法として、FEM 解析による引張特性 の予測が挙げられる。FEM を活用することにより、実験では評価 できていない形状での引張特性を補完・予測できるというメリット がある。本章では、過去に提案された積層ゴムの引張特性を予測す る解析モデルを用いて、積層ゴムの引張弾性率の各種依存性の予測 精度の検証を行った。本研究では、「フランジ厚さ依存性」、「2 次形 状係数依存性」「オフセットせん断ひずみ依存性」の依存性を FEM で再現できるかを検証した。ここでは、表 $3 \sim 5$ に示した 9 ケース の解析を行った(表 3、表 4 の No.5 の試験は同一試験のため、合せ て1ケースとした)。

FEM 解析モデルの検証は、以下の手順で行った。

(1) ゴム外径 $225 \mathrm{~mm} 、 \mathrm{~S}_{2}=5$ 、フランジ端部厚 $11 \mathrm{~mm}$ の試験体にお ける「オフセット $0 \%$ の単純引張試験(試験体 No.8)」と「面圧 
$0 \mathrm{MPa}$ での単調載荷試験(試験体 No.12)」に合うようにゴムの 材料パラメータを決定。

（2）表 3〜 5に示したその他の8ケースの解析における引張解析を 行い、引張特性の各種形状パラメータ依存性を再現できるかを 調べることで FEM 解析モデルの妥当性を検証。

\section{1 解析モデル}

本解析においては FEM 解析ソフト MSC.MARCを用いた。計算負 荷軽減を目的として、対称性を考慮した $1 / 2$ モデルにて解析を行っ た。解析モデルを図 12 に、境界条件を表 14 に示す。内部鋼板、フ ランジ、ボルトについては 8 節点六面体次数低減積分要素を、ゴム については 8 節点六面体完全積分要素を用いた。後述する通り、ゴ ムについては筆者ら提案の構成則を用いたため、MSC.MARC に用 意されているユーザーサブルーチン Hypela2 を用いた ${ }^{20)}$ 。

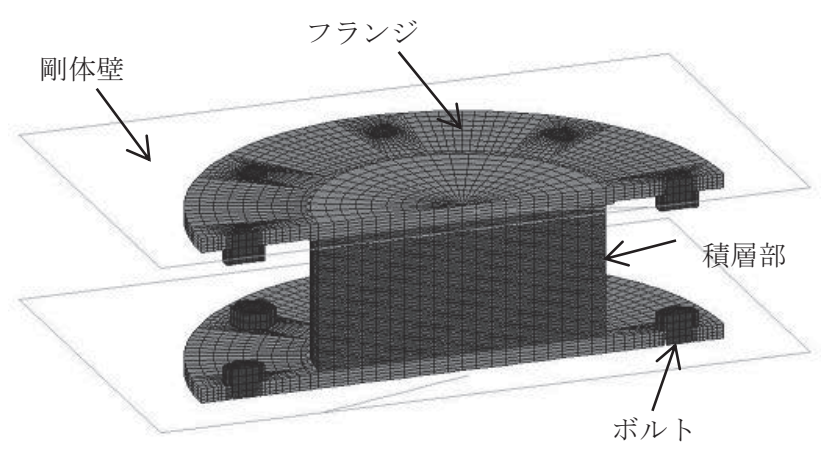

図 12 解析モデル(試験体 No. 4 の例)

表 14 各部材間の境界条件

\begin{tabular}{|l|l|}
\hline & 境界条件 \\
\hline \hline ジムと内部鋼板・フランジ & 節点共有 \\
\hline 岡体壁とフランジ & 摩擦 0 で接触 \\
\hline ボル座面とフランジ & 摩擦係数 1.0 で接触 \\
\hline ボルト底面と剛体壁 & 固着接触 \\
\hline $\begin{array}{l}\text { ボルトのネジ部と } \\
\text { フランジのボルト穴側面 }\end{array}$ & 非接触 \\
\hline
\end{tabular}

\section{2 材料モデル・材料定数}

内部鋼板・フランジはバイリニア型の弾塑性体を仮定し、降伏条 件は Mises 条件とした。ボルトは完全弾性体とした。ベースプレー 卜は剛体を仮定し、フランジ上下部に回転も拘束した剛体壁を設け た。ゴムについては、筆者らにより提案した、一様 3 軸引張が生じ た際の剛性低下を表現できる式(1)〜(3)の超弾性構成則を用いた ${ }^{12)}$ 。 この材料モデルは、2、3 章で示したような積層ゴムの引張変形時 のボイド発生による剛性低下を表現できるモデルとなっている。内 部鋼板・フランジ・ボルトの材料定数を表 15 に、ゴムの材料定数を 表 16 に示寸。内部鋼板・フランジ・ボルトの材料定数は文献 13)で 使われている值を用いた。ゴムの材料定数については、今回実施し たオフセット $0 \%$ の引張試験(表 5 の No.8)における引張応力一引張ひ ずみ関係に合うように $\kappa_{2}, \kappa_{3}, \varepsilon_{1}$ を決定し、オフセット $400 \%$ 試験(表 5 の No.12)におけるせん断応力一せん断ひずみ関係に合うように $a, b$ を決定した。オフセット $0 \%$ の引張試験(表 5 の No.8)における引張応 カー引張ひずみ関係の実験と解析の比較結果は図 6(a)に、オフセッ 卜 400\%試験(表 5 の No.12)におけるせん断応力一せん断ひずみ関係

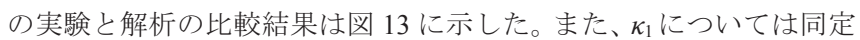

が難しいため、文献 13)の圧縮弾性率の值 1000MPa を用いた。

$$
\begin{aligned}
& W=W_{\mathrm{dev}}+W_{\mathrm{vol}} \\
& W_{\mathrm{dev}}=a\left(I_{1}-3\right)+b\left(I_{1}-3\right)^{3}
\end{aligned}
$$

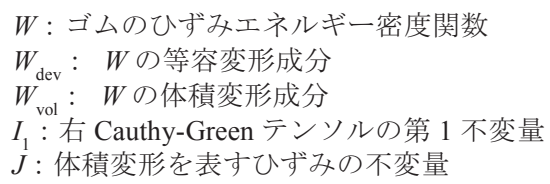

$a:$ 材料定数(線形ば衫を表す)

$b:$ 材料定数(ハードニングを表す)

$\kappa_{1}:$ 材料定数(圧縮剛性を表す)

$\kappa_{2}:$ 材料定数(引張の初期剛性を表す)

$\kappa_{3}:$ 材料定数(引張降伏後の剛性を表す)

$\varepsilon_{1}^{3}:$ 材料定数(引張降伏ひずみを表す)

表 15 材料定数 (内部鋼板・フランジ・ボルト)

\begin{tabular}{|c|c|c|c|c|}
\hline & $\begin{array}{c}\text { ヤング率 } \\
(\mathrm{GPa})\end{array}$ & $\begin{array}{c}\text { ポアソン比 } \\
(-)\end{array}$ & $\begin{array}{c}\text { 降伏応力 } \\
(\mathrm{MPa})\end{array}$ & $\begin{array}{c}\text { 降伏後剛性 } \\
(\mathrm{GPa})\end{array}$ \\
\hline \hline $\begin{array}{c}\text { 内部鋼板 } \\
\text { フランジ }\end{array}$ & 205 & 0.3 & 235 & 5.2 \\
\hline ボルト & 205 & 0.3 & - & - \\
\hline
\end{tabular}

表 16 材料定数 (ゴム)

\begin{tabular}{|c|c|c|c|c|c|}
\hline $\begin{array}{c}a \\
(\mathrm{MPa})\end{array}$ & $\begin{array}{c}b \\
(\mathrm{MPa})\end{array}$ & $\begin{array}{c}\kappa_{1} \\
(\mathrm{MPa})\end{array}$ & $\begin{array}{c}\kappa_{2} \\
(\mathrm{MPa})\end{array}$ & $\begin{array}{c}\kappa_{3} \\
(\mathrm{MPa})\end{array}$ & $\begin{array}{c}\varepsilon_{1} \\
(-)\end{array}$ \\
\hline \hline 0.202 & 0.000224 & 1000 & 65 & -0.1 & 0.0192 \\
\hline
\end{tabular}

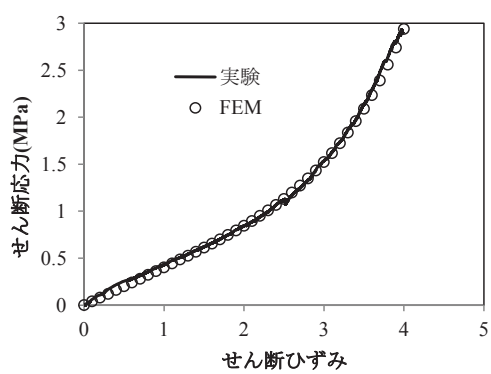

図 13 せん断応カーせん断ひずみ関係の実験と解析の比較

\section{3 解析結果}

図 8 と同様にオフセットせん断ひずみ $250 \%$ 、引張ひずみ $75 \%$ 変 形時の Mises 応カコンター図を図 14 に示す。定量的な比較はして いないが、図 8 と比較して変形状態は概ね再現できていることがわ かる。

引張応力ー引張ひずみ関係の解析結果と実験結果の比較は図 4〜 6 に示した。若干の乘離はあるものの、引張挙動を再現できている ことがわかる。二次形状係数、フランジ厚、オフセットせん断ひず み依存性の傾向も概亦再現できている。特に、引張ひずみ $50 \%$ 以下 
の領域で、オフセットせん断ひずみ $250 \%$ 以下ではオフセットせん 断ひずみの増加とともに剛性が低下し、オフセットせん断ひずみ $250 \%$ 以上ではオフセットせん断ひずみの増加とともに剛性が高く なる傾向を再現できている。オフセットせん断ひずみ 0 ～ $250 \%$ の間 で、オフセットせん断ひずみの増加とともに引張弾性率が低下寸る のは、オフセットせん断ひずみが大きい程、局部的に引張変形が生 じ、それに伴う局部的な剛性低下の発生が原因と考えられる。図 14 に示した FEM の結果からも、積層ゴムの左上端と右下端で引張変 形が集中していることがわかる。また、オフセットせん断ひずみが $250 \%$ 超えると、水平ハードニングの影響が顕著となり、オフセッ 卜せん断ひずみの増加とともに引張弾性率が増大寸ると考えられる。 Et4 の解析結果と実験結果の比較を表 17 に示寸。概敉引張弾性率 が一致しており、提案した FEM 解析モデルを用いて、引張弾性率 等の評価に十分適用可能な精度を有していると考えられる。よって、 提案した解析モデルにより、実験で評価できていない形状の積層ゴ ムの引張特性を十分に補完・予測できると考えられる。ただし、提 案されたゴムの材料モデルは、繰返しによる剛性の低下は考慮でき ていない。繰返しによる剛性低下の際現には、ダメージ関数等を導 入する必要があると考えられ、今後の課題である。

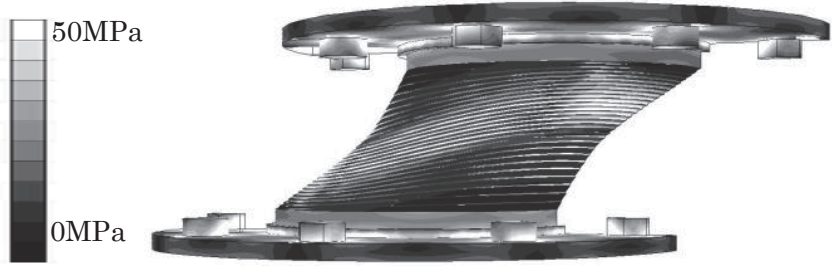

図 14 Mises 応カコンター図

表 17 引張弾性率 Et4 の実験と解析值の比較

\begin{tabular}{|c|c|c|c|c|c|c|}
\hline $\begin{array}{c}\text { 試験 } \\
\text { 体 } \\
\text { No. }\end{array}$ & $\begin{array}{c}\text { オフセッ } \\
\text { トせん断 } \\
\text { ひずみ }\end{array}$ & $\begin{array}{c}2 \text { 次 } \\
\text { 形状 } \\
\text { 係数 }\end{array}$ & $\begin{array}{c}\text { フランジ } \\
\text { 厚/゙゙ム } \\
\text { 外径 }\end{array}$ & $\begin{array}{c}\text { Et4 } \\
\text { (実験) }\end{array}$ & $\begin{array}{c}\text { Et4 } \\
\text { (解析) }\end{array}$ & $\begin{array}{c}\text { 実験值 } \\
\text { 対比 } \\
\text { 誤差 }\end{array}$ \\
\hline \hline 8 & $\underline{\mathbf{0}}$ & 5.02 & 0.049 & 36 & 33 & $-8 \%$ \\
\hline 9 & $\underline{\mathbf{1 5 0}}$ & 5.02 & 0.049 & 26 & 27 & $4 \%$ \\
\hline $10^{* 1}$ & $\underline{\mathbf{2 5 0}}$ & 5.02 & 0.049 & 22 & 25 & $14 \%$ \\
\hline 11 & $\underline{\mathbf{3 0 0}}$ & 5.02 & 0.049 & 24 & 25 & $4 \%$ \\
\hline 12 & $\underline{\mathbf{4 0 0}}$ & 5.02 & 0.049 & 30 & 29 & $-3 \%$ \\
\hline $5^{* 2}$ & 250 & $\underline{\mathbf{3 . 5 2}}$ & 0.049 & 20 & 20 & $0 \%$ \\
\hline $7^{* 1}$ & 250 & $\underline{\mathbf{5 . 0 2}}$ & 0.049 & 23 & 25 & $9 \%$ \\
\hline 4 & 250 & 3.52 & $\underline{\mathbf{0 . 0 3 1}}$ & 19 & 19 & $0 \%$ \\
\hline $5^{* 2}$ & 250 & 3.52 & $\underline{\mathbf{0 . 0 4 9}}$ & 20 & 20 & $0 \%$ \\
\hline 6 & 250 & 3.52 & $\underline{\mathbf{0 . 0 8 0}}$ & 22 & 21 & $-5 \%$ \\
\hline
\end{tabular}

*1 同一形状の試験体 2 基で実施。 *2 同一試験の結果。

\section{6. まとめ}

免震構造物の設計において、引張限界を従来の引張限界応力での 設計ではなく、引張限界ひずみにて設計するための引張限界ひずみ を実験的に評価した。具体的には、引張限界ひずみの妥当性を評価 する為に、限界引張ひずみを規定する為の特定の引張ひずみを与え
た前後で、基本性能や限界性能に影響が無いことを確認した。特定 の引張ひずみは $15 \%$ とし、張限界ひずみはそれに安全を見て $5 \%$ として提案した。また、引張限界ひずみで設計する場合、引張弾性 率の值が必要であるため、本研究では、「フランジ厚さ依存性」、「2 次形状係数依存性」、「オフセットせん断ひずみ依存性」、「繰返し」 に対する依存性を調べ、引張弾性率の設定方法を提案した。

更に、過去に提案された積層ゴムの引張特性を再現できる FEM 解 析モデルを用いて、本研究における引張弾性率等の評価に十分適用 可能であることを示した。

\section{参考文献}

1) A. N. Gent, P. B. Lindley : Internal rupture of bonded rubber cylinders in tension, Proc. Roy. Soc., 249, pp.195-205, 1959

2）納富充雄，下坂陽男，下田博一，鈴木重信，芳沢利和：引張負荷による免 震用ゴム材料のボイド生成，日本機会学会論文集(A 編)，68 巻，669 号， pp.52-57, 2002.5

3）矢口大輔他：超高層免震構造の開発と適用 その 4 , その 5 , 日本建築学会 大会学術講演梗概集 B-2, pp595-596, 1998

4）内山義英他：超高層免震構造の開発と適用 その 3 , 日本建築学会大会学 術講演梗概集 B-2, pp593-594, 1998

5）藤波健剛他：ゴムリングを用いた $\varphi 1100$ 積層ゴムの性能確認試験 その 1 4, 日本建築学会大会学術講演梗概集 B-2, pp219-226, 2010

6）熊澤千果生他：ゴムリングを用いた $\varphi 1300$ 積層ゴムの性能確認試験 そ の 1 ～3, 日本建築学会大会学術講演梗概集 B-2, pp493-498, 2011

7）荻野伸行他:IBT ワッシャーを用いた $\varphi 1100$ 積層ゴムの性能確認試験 そ の 1 ～3, 日本建築学会大会学術講演梗概集 B-2, pp837-842, 2009

8）山崎慎介他：ストッパーピンと軸受を用いた積層ゴム支承の引抜対応機 構の開発 その 1 , その 2 , 日本建築学会大会学術講演梗概集 B-2, pp509-512, 2011

9）菊地隆志他：引抜を受けた積層ゴムの特性変化について,日本建築学会大 会学術講演梗概集 B-2, pp539-540, 1997

10）森隆浩，加藤秀章，室田伸夫 : 変形履歴積分型の弾塑性構成則を用いた 高減衰積層ゴムの FEM 解析，日本建築学会構造系論文集，第 75 巻，第 658 号, pp.2171-2178, 2010.12

11）森隆浩, 加藤秀章, 室田伸夫 : 繰返し変形による疲労と温度上昇の効果 を取り入れた高減衰積層ゴムの解析モデルの提案, 日本建築学会構造系 論文集，第 77 巻，第 680 号, pp.1517-1526, 2012.10

12）森隆浩，室田伸夫，菊地隆志：ボイド発生によるゴムの剛性低下を考慮 した超弾性構成則による積層ゴムの引張り変形及び水平大変形 FEM 解 析，日本建築学会構造系論文集，第 76 巻，第 663 号, pp.917-925, 2011.5

13）森隆浩他：高い変形能力を有する 2 段組み積層ゴムの力学挙動 その 4 , 日本建築学会大会学術講演梗概集 B-2,pp413-414, 2010

14）森隆浩他：高い変形能力を有する 2 段組み積層ゴムの力学挙動 その 7 , 日本建築学会大会学術講演梗概集 B-2,pp503-504, 2011

15）(株)ブリヂストン：天然ゴム系積層ゴム技術資料, 2009.4

16）松田泰治，大鳥靖樹，平田和太，石田勝彦：加熱促進試験による天然ゴム 系積層ゴムの経年変化特性評価, 日本建築学会大会学術講演梗概集 B-2, pp717-718, 1996.9

17）大鳥靖樹 : 積層ゴム免震要素の引張許容応力に関する検討, 日本建築学 会大会学術講演梗概集 B-2, pp.535 536、1997.9

18) Mullins L.: Effect of stretching on the properties of rubber., Rubber Chem.Technol., 21, pp281-300, 1948

19）岡本修司，高山峰夫，森田慶子，和田章，可児長英 : 免震構造用積層ゴム の引張特性に関寸る実験研究 その 1 , 日本建築学会九州支部研究報告, 第 40 号, 2001.3

20） MSC.MARC ユーザーズマニュアル D 編, 2003 


\section{EVALUATION OF TENSILE CHARACTERISTICS OF RUBBER BEARINGS TO DESIGN SEISMICALLY ISOLATED STRUCTURE BY DESIGN LIMIT VALUE OF TENSILE STRAIN}

\section{Takahiro MORI ${ }^{* 1}$, Masahiro NAKAMURA*2, Nobuo MUROTA*3, Haruyuki KITAMURA*4 and Toshiaki SATO *5}

\footnotetext{
${ }^{* 1}$ Infrastructure Products Development Dept., Bridgestone Co., Dr.Sci.

*2 Infrastructure Products Development Dept., Bridgestone Co., Dr.En

${ }^{*}$ Infrastructure Products Development Dept., Bridgestone Co., Ph.D ${ }^{* 4}$ Prof., Dept. of Architecture, Tokyo Univ. of Science, Dr.Eng.

${ }^{* 5}$ Assist. Prof., Dept. of Architecture, Tokyo Univ. of Science, Dr.Eng.
}

Owing to growing interest in seismic safety and disaster prevention, seismically isolated buildings (mid-to-high-rise buildings in particular) are increasing. In recent years, seismically isolated buildings, such as exceeding the height $100 \mathrm{~m}$ has also become common. In the case of designing high-rise building or building which has set back, it can happen which tensile force occurs at part of isolator. Currently, laminated rubber bearing is the most major isolator in Japan. Generally, while laminated rubber bearing has high stiffness against compression, it has low stiffness against tension. This is because rubber rigidity decreases due to voids generated inside the rubber, when a laminated rubber bearing is subject to tensile deformation. Therefore, when designing a seismically isolated building, it is necessary to avoid occurrence of excessive tension for a laminated rubber bearing. The design limit tensile value is defined by the tensile stress value, and its value is uniformly $1 \mathrm{MPa}$ regardless of the type of the laminated rubber bearing at present. In the case of occurring more than 1MPa of tensile stress for laminated rubber bearing, its laminated rubber bearing must be taken replaced by special type of isolator.

In case seismically isolated structure is designed using design limit tensile stress value, tensile stress often transcends $1 \mathrm{MPa}$. Using special type of isolators becomes constrain to designing seismically isolated structure. In order to loosen this constrain, a method which tensile design limit value is defined by tensile strain is proposed in this paper. While laminated rubber bearing has weak in the vertical tension, it is true that it has a high deformation capacity. Therefore, by designing a seismic isolation structure by the design limit tensile strain value, seismically isolated buildings such as high-rise buildings are designed without using special type of isolators.

Under this background, main object in this study is to define design limit value by not conventional tensile stress but tensile strain. To do this, it is necessary to properly evaluate the design limit tensile strain value by performing proper tensile test of laminated rubber bearings. In the case of designing seismically isolated structure, tensile stiffness must be defined as well. Therefore, various tensile tests are carried out and a method of determining design limit tensile strain value and tensile stiffness is proposed.

In general, it takes a great deal of effort into experimental evaluation of laminated rubber bearing. As a technique to reduce these labors, finite element analysis (FEA) is widely used. In the past, a material model which can represent a behavior of tensile deformation of laminated rubber bearing is proposed by the authors. In this study, we show the validity of proposed FEA model by comparing with test results.

This paper is constructed as follows. In Section 2, an outline of the tensile experiment of laminated rubber is shown, and its experimental results are shown in Section 3. Based on the experimental results, in Chapter 4, a method of determining design limit tensile strain value and tensile stiffness is proposed. In chapter 5, prediction accuracy by FEA is shown. Finally, in Chapter 6, summary and conclusions of this study are shown. 